\title{
Being Mama Papua is One of the Result of Tri Rismaharini in Implementing Community Relations
}

\author{
Siska Armawati Sufa, Bachrul Amiq, Slamet Riyadi \\ Dr. Soetomo University \\ Surabaya, Indonesia \\ siska.armawati@unitomo.ac.id
}

\begin{abstract}
Much of community relations, however, is unintentional, as well as Risma, first women's mayor in Surabaya city also appealed the citizens of Surabaya to care and provide assistance to the people of Papua, if the people of Surabaya help other people affected by disaster, then the city of Surabaya will be protected from disaster. Community relations through a goodwill approach, can be profitable in the event of a crisis management process - the better organizations connected to the external environment, are getting ready to face the crisis. This makes Surabaya more secure than any other city in Java, especially from the demonstration action by Papuan students, since the initial investment made by Risma in community relations always requires less time and money rather than a spontaneous reaction to a crisis situation. Risma has gained a special place in the hearts of the Papuans as a Mama for all of them, with all his humility in building community relations through a more specific approach of human relations for his sincerity in helping to improve the ability of the people of Papua in all areas of life.
\end{abstract}

Keywords- community relations; system approach; Papuans; Mama Papua

\section{INTRODUCTION}

The relationship of the organization with its public is increasingly complex as the dynamics the surrounding environment. There are several things that affect relationships organization with its public, as happened in Indonesia.

Grunig and Hunt [1] emphasize that nne of the public that contributes to build reputation of organization is community. The community is understood as a group of people which has an interest and is related to the existence of the organization, as well as geographically located in the area around the organization. The existence of community becomes important for the continuity of existence organizations remember the community is a community group living in a certain geographical area, which is also a part of the environment in which the organization is located.

The government has a very wide authority as a regulator of the life of the state and society. Government and all officials have a great influence on various forms of community relations. Even the Government can play a mediating role in overcoming the crisis. The government's decision is in addition to a reflection of the needs of society, often also a reflection of opinion from officials.
Community relations is an effort to foster harmonious relationships between organizations with communities to increase social awareness and mutual understanding. Community relations is basically a public relations activity, so the steps in the public relations process color the steps in community relations. Remembering that community relations face on directly with the real social issues facing the community around the organization through a community relations approach, the organization together with the surrounding community seeks to identify, find solutions and act an action plan on the issues at hand [2].

Wilbur [3] in a book titled "Community Relations" in Lesly's Public Relations Handbook define that community relations, as a public relations function, is a institution's planned, active, and continuing participation with and within a community to maintain and enhance its environment to the benefit of both the institution and the community.

Community relations is a planned activity of an organization. There are several alternative managerial stages on offer, but in essence is the same. Kelly [4] proposed, found five managerial stages: research, goal setting, programming and implementation, evaluation and ending with mentoring.

Community relations is one part of public relations when viewed from the public type [5]. Community relations as one form of public relations, consisting of institutional participation with planned, active, and continuous in the community to maintaining and make improvements to the environment for profit and goodness communities and institutions themselves. The focus of community relations is to build good relationships with the community. This is very different from other types of public relations activities in terms of media relations, consumer relations and media relations.

Community relations require organizations to understand priorities of the communities in which they interact, and because of the community itself is multi-national then the aspect is then selected as a community relations must be able to capture the interests of every part of the community within universality [6]

Community relations programs are implemented to achieve some aim [7] are: 1) provide information to the community about the organization itself, the products produced, the services provided and the activities undertaken; 2) straighten out misunderstandings and responding to public criticism with 
efforts to mobilize support and opinions positive; 3) get legal support that will affecting community work climate; 4) know attitude, knowledge and community expectations; 5) supporting health facilities, education, recreation and cultural activities; 6) get good recognition from the local government; 7) fostering the local economy by buying goods needs of the local area.

In the implementation of the Public Relations function, local communities are viewed as a unity with organizations that provide mutual benefits. Grunig and Hunt in a book titled "Managing Public Relations" [8] said there are two kinds of community, namely: 1) as a locality, people are gathered because of geographical location; 2) communities are not only based on geographical location but are based on the interests of people who share the same interests such as the scientific community, and the business community. In this case the focus is the problem facing the community. Not the problem facing the organization. But the impact of solving the problems facing the community will be felt also by the organization, given that community relations programs are basically developed for the common good of organizations and communities.

Organizational dynamics can occur due to internal influences in the form of conflict which occurs between the organizers of the organization or the cohesiveness excessive from the destructive group of organizations cooperation within organizations and external influences in the form of influence of environmental factors such as market, economic conditions, political pressures of technological change as well as the physical condition of the environment [9]. This means that the leader has a dual role, responsible for bringing the organization into the environment beyond the ever-changing organization and in turn forcing the organization to adapt [10].

Surabaya is a city that has dynamic and well-ordered community characteristics. This condition is very potential to attract investors from abroad. Good reputation and achievement of Surabaya is the result of Tri Rismaharini's efforts as a mayor by doing many positive breakthroughs for the community.

Tri Rismaharini or Risma, mayor of Surabaya is the first female mayor democratically elected post-reformation. She appeared as the transformational leadership that brings a remarkable achievement for Surabaya. Leadership style is often in the spotlight many parties and is always awaited by the public. Surabaya leader who mentioned as emotional leader, has not hesitate to upset if things go wrong and sometimes cry just like an ordinary woman. But she has a tremendous empathy and concern for its citizens. Purwati Ayu Rahmi's thesis [10] about Leadership of Head of Region, Tri Rismaharini in Perspective Emotional Intelligence shows that Risma has strong leadership in this aspect of self-emotional intelligence, confidence, achievement, initiative, optimism, service, develops the community, and agents of social change for the community of Surabaya City. However, Risma is very weak in terms of self-control. Competence are not maximal accuracy of self-assessment, transparency, adaptability, empathy, awareness in organization, inspiring, influencing, conflict management, teamwork and collaboration.
One of the results of Risma's efforts to build good relationships with the community is by obtaining an award as Mama Papua, because Risma is considered to have protected the Papuans living in Surabaya. Mama Papua is the first award of the Papuans, in other regions there has never been a head of the region who earned that award. Risma is expected by Papuans to be role models for citizens and local government in Papua. Papuans want development in Papua to be like Surabaya. Many development policies can be replicated from Surabaya. After becoming Mama Papua, Risma conveyed his appeal to the people of Papua in Surabaya so as not to hesitate to ask for help from the city government of Surabaya, he also promised to be a substitute for mama for students from Papua away from their original residence [11].

\section{RESEARCH METHOD}

This study uses a systemic approach which is one of the alternatives to see the relation organization with its public. The organization itself is a system [12] ie a set of interacting units that endures through time within an established boundary by responding and adjusting to change pressures from the environment to achieve and maintain the goal states. The system consists of several sub-systems and surrounded by other systems interdependent with each other. Therefore, the formulation of the problem in this research is about how Risma as mayor of Surabaya in implementing community relations program is real face to face with social problems with the Papua community around the city. This study uses a qualitative approach, through interview techniques to Tri Rismaharini (key informant), Government-PR Division of Surabaya City and Papua community (informant), based on Research Design: Qualitative, Quantitative, and Mixed Method Approaches [13], to get a picture of the phenomenon to be studied, obtained from a number of data, researchers in qualitative research get data from the results of interviews, observation, and documentation, then researchers review all the results of the data, understand, and organize into the categories relevant to the data source.

\section{RESULT AND DISCUSSION}

Much of community relations, however, is unintentional, as well as Risma, first women's mayor in Surabaya city also appealed the citizens of Surabaya to care and provide assistance to the people of Papua in districts of Asmat and Bintang that experienced malnutrition. Risma thought that if the people of Surabaya help other people affected by disaster, then the city of Surabaya will be protected from disaster.

Community relations through a goodwill approach, can be profitable in the event of a crisis management process - the better organizations connected to the external environment, are getting ready to face the crisis. This makes Surabaya more secure than any other city in Java, especially from the demonstration action by Papuan students, since the initial investment made by Risma in community relations always requires less time and money rather than a spontaneous reaction to a crisis situation.

Risma gives equal treatment to all its citizens in Surabaya, trying to build emotional approaches with the whole society. Risma explained that humans can not choose to be born from 
which tribe and religion, "Everything is given, something that is destined and we can not but accept it".

In this case, Risma has implemented community relations with a more specific context to the people of Surabaya from various backgrounds, namely human relations by interacting with a group of people who concerning human relations and moral ethics that aims to obtain satisfaction for both parties.

The charm of the Mayor of Surabaya Tri Rismaharini apparently has its own place for the people of Papua. Risma's strict leadership style and still prioritize children, making the Association of Papuans give a special name for Risma named Mama Papua. Embedding the name of the Mama Papua took place at Graha Sawunggaling Surabaya on January 21st, 2017. When embedding as Mama Papua, Risma pinned a Cenderawasih crown cap, a Papuan batik shawl and a noken knit root bag. In front of the Papuan Community Association, Risma affirmed that all Papuan children who are in knowledge in Surabaya might at any time meet him. Risma appealed to all Papuan children who are studying in Surabaya in order to be role models. Papuan children are expected to bring their regional name to the international scene with a myriad of achievements [14]. "The crown bearing the Cenderawasih bird that we gave to Mrs. Risma, as a sign that Risma got the nickname Mama Papua. This is the highest award from the people of Papua" (an excerpt from an interview with Fredy Rumbara, one of the elders of the Papuan community).

"Risma is a leader who builds without regard to wealth and himself but more for the progress of the region and its citizens" (an excerpt from an interview with Opa Musa, a Papuan religious leader). For his performance, young peoples from Cendrawasih Habitat, who studied and worked in Surabaya, secretly admire to this number one woman in Surabaya. In Surabaya City Government, heads of local government work units do have different backgrounds and not only from Java island, but from various islands ranging from Sumatra, Kalimantan, Sulawesi to Papua. During this time they can cooperate well in organizing and managing the city of Surabaya. According to Kreps [15], there are important implications of system approach to understanding the organization. The first implication is interdependence shows between one part and another part mutually related. To achieve effective organizational work then the whole, such functional parts should be coordinated through communicating. Activity communication is used to share information and mutual persuasive to cooperate. The second implication, in the system approach is shown how openness brings implications for organizations to realize environmental change.

The system approach is believed to be capable of explaining interdependence organization with its environment in carried out activities to achieving aim. "All Papuans have the same rights to study at various schools and universities in Surabaya, therefore it takes the cooperation of the community of Papua to cooperate to maintain the security stability of Surabaya city" (an excerpt from an interview with Risma, mayor of Surabaya), because however some student communities in some areas of Surabaya are prone to conflicts leading to anarchist actions, one of which is the Papuan student community who is studying at several universities in Surabaya.
The Papuans consider that Risma has succeeded in bring forth to economic heroes in Surabaya, therefore, the mothers of church activist in the Papua region want to learn much from risma, especially about the creative economy, such as: culinary business, home industry and agricultural.

Risma hope that the success of Surabaya to build an economy based on community participation can also be felt by other regions, especially eastern Indonesia such as Papua. organization with the public is considered to have no impenetrable dividing boundaries. The organization views the public as part of the participating organization determine the life of the organization. The organization is trying to find out needs, expectations and public opinion relating to the organization, which is then used as input and consideration to making organizational decisions. Thus the real organization policy is the result of mutual agreement from both parties.

With regard to community relations, an open system approach believed to be able to empower the public, given the public is placed in a balanced position, interdependent and not dominating each other. An open system approach in relation to community relations developed more specifically into a communitarian approach [16].

Risma also provides a special space for all young people, especially students to be able to discuss and share the latest information about creative economy, namely KORIDOR - Co Working is the commitment of Surabaya City Government to create envoronment that empowers local creators, innovators and entrepreneurs to create innovation and able to compete on a global level. As part of the vision of the Mayor of Surabaya, Tri Rismaharini, to make Surabaya a creative and technological center on a global level, KORIDOR is the first step to build and strengthen the foundations of creative economy at the local level.

Papuan students in Surabaya get an opportunity also to develop insights related to creative economy, entrepreneurship, information technology on every Sunday afternoon in KORIDOR. Fig. 1 is Papua students along with other students are discussing audio-visual with the film director of "Ada Apa dengan Cinta?".

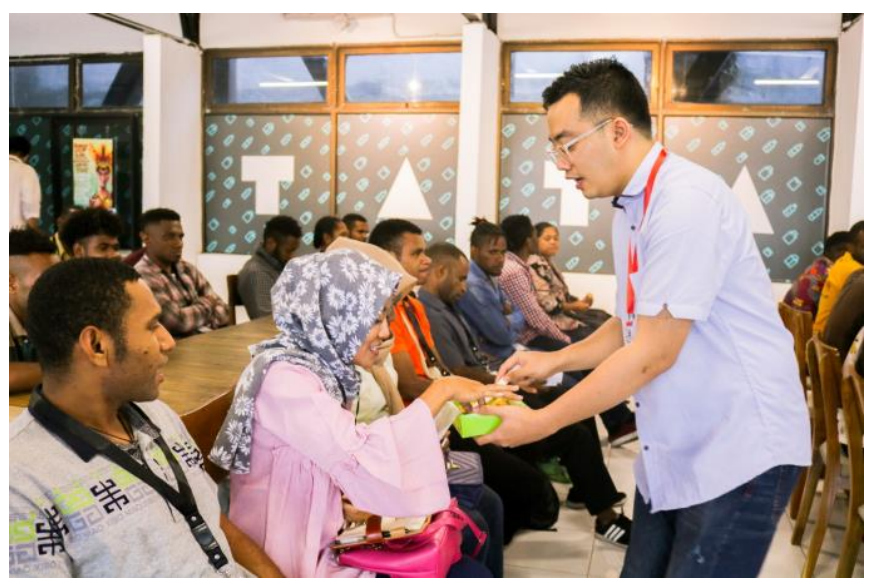

Fig. 1. Papua students along with other students are discussing audio-visual with the film director of "Ada Apa dengan Cinta?" 
Building local community relationship can be the most important communication activity undertaken by an organization. Since any organization can expect to communicate with a range of community audiences including the media, the general public and local communities, an effective communication plan must needs to be implemented.

\section{CONCLUSION}

Risma as the first female mayor in Surabaya has gained a special place in the hearts of the Papuans as a mama for all of them, with all his humility in building community relations through a more specific approach of human relations for his sincerity in helping to improve the ability of the people of Papua in all areas of life.

\section{ACKNOWLEDGMENT}

A project of this magnitude requires a network of support. I am particularly grateful to proudly mayor, Tri Rismaharini and Muhammad Vikser as a Government PR of Surabaya city for making the study possible, and to Bachrul Amiq as a rector and Slamet Riyadi as a vice rector of Dr. Soetomo University Surabaya, Novi Rizki Amalia as my staff, and my three guardian-angel: Langit, Jagad, Arka, for their unyielding encouragement and support. I will continue to develop research on community relations studies, especially about the Government-PR.

\section{REFERENCES}

[1] A. Yudarwati, "Community Relations: Bentuk Tanggung Jawab Sosial Organisasi”. Yogyakarta: Atmajaya University, 2004.

[2] A. Youna C. Bachtiar, "Stakeholder Relations, Modul Perkuliahan Community Relations" 2, topic 9, online 6. Jakarta: Mercubuana University, 2015.

[3] P. Lesly, "Handbook of Public Relations, 5th edition", Lincolnwood, Ill. U.S.A.: Contemporary Books, 1998.
[4] K.S. Kelly, "Stewardship: The Fifth Step in The Public Relations Process", in R.L. Heath and V. Gabriel (eds), "Handbook of Public Relations". California: Sage Publication, Inc., 2001.

[5] D. Lattimore, O. Baskin, S.T. Heiman, E.L. Toth, "Public Relation: The Profession and the Practice", New York: McGraw Hill, 2010.

[6] Y.P. Putra, "Program CSR sebagai Penerapan Community Relations: Studi Kasus "Living with HIV" oleh Salah Satu Bank Internasional yang Memiliki Cabang Pusat di Indonesia”. Surabaya: Universitas Airlangga, 2013.

[7] S.M. Cutlip, A.H. Center, G.M. Broom, "Effective Public Relations, 8th edition”. New Jersey: Prentice Hall, 2011.

[8] J.E. Grunig, and T. Hunt, "Managing Public Relations". New York: Holt, Rinehart \& Winston, 1984.

[9] P. Hutapea, N. Thoha, "Kompetensi Plus Teori, Desain, Kasus dan Penerapan untuk HR serta Organisasi yang Dinamis". Jakarta: Gramedia, 2008.

[10] P.A. Rahmi, "Kepemimpinan Kepala Daerah (Studi kasus Walikota Surabaya, Tri Rismaharini dalam Perspektif Emotional Intelligence0", Surabaya: Airlangga University, 2015.

[11] S.E. Prasetyo, "Lindungi Warga Papua di Kota Pahlawan, Risma Jadi Mama Papua", cited from: https://www.jawapos.com/read/2017/01/22/104151/lindungi-wargapapua-di-kota-pahlawan-risma-jadi-mama-papua, on: Tuesday, December 05th, 2017

[12] S.M. Cutlip, A.H. Center, and G.M. Broom, "Effective Public Relations, 8th edition". New Jersey: Prentice Hall, 2011.

[13] J.W. Creswell, "Research Design: Qualitatif, Quantitatif, and Mixed Method Approaches, 3rd edition". California: Sage Publications, Inc, 2009.

[14] R. Nurwawati, "Jadi Mama Papua, Tri Rismaharini: Saya Adalah Mama Kalian Semua", cited from: http://www.tribunnews.com/regional/2017/01/21/jadi-mama-papua-trirismaharini-saya-adalah-mama-kalian-semua, on: Monday, December 18 th, 2017.

[15] G.L. Kreps, “Organizational Communication”. New York: Longman, 1986.

[16] L.J. Wilson, 2001, "Relationships within Communities: Public Relations for The New Century", in R.L. Heath (ed), Handbook of Public Relations. California: Sage Publication, Inc. (page. 521- 526), 2001. 